\title{
Relation between lung function, exercise capacity, exposure to asbestos cement
}

\author{
P WOLLMER, ${ }^{1}$ L ERIKSSON, ${ }^{1}$ B JONSON, ${ }^{1}$ KR ISTINA JAKOBSSON ${ }^{2}$ \\ MARIA ALBIN, ${ }^{2} S$ SKERVING, ${ }^{2}$ H WELINDER ${ }^{2}$ \\ From the Departments of Clinical Physiology ${ }^{1}$ and Occupational Medicine, ${ }^{2}$ University of Lund, Lund, Sweden
}

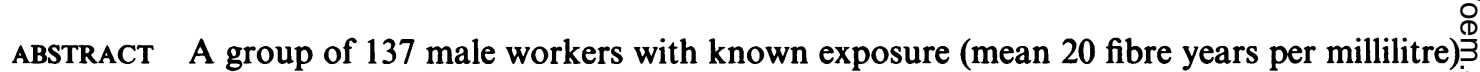
to asbestos cement who had symptoms or signs of pulmonary disease was studied together with af reference group of 49 healthy industrial workers with no exposure to asbestos. Lung functionio measurements were made at rest and during exercise. Evidence of lung fibrosis was found as well as $\mathrm{N}$ of obstructive airways disease in the exposed group compared with the reference group. Asbestoso cement exposure was related to variables reflecting lung fibrosis but not to variables reflecting airflow obstruction. Smoking was related to variables reflecting obstructive lung disease. Exercise capacity was reduced in the exposed workers and was related to smoking and to lung functiono variables, reflecting obstructive airways disease. There was no significant correlation between exer- $-\stackrel{\infty}{\square}$ cise capacity and exposure to asbestos cement.

It is well established that occupational exposure to asbestos dust may cause interstitial pulmonary fibrosis (asbestosis) and impaired gas exchange. ${ }^{12}$ There is also evidence that such exposure may cause airway obstruction. ${ }^{3-7}$ Exposure response relations have been established for radiographic ${ }^{89}$ and for functional $l^{81011}$ indicators of interstitial fibrosis. Little is known, however, about the risk of lung function impairment associated with low level exposure to asbestos. There is also little information available about the effects of asbestos induced lung function impairment on exercise capacity. ${ }^{12-15}$ This is unfortunate as it makes judgments on the compensation for disability difficult.

The principal aim of the present paper was to study lung function in workers exposed to low or moderate levels of asbestos dust and to analyse the relations between exposure, lung function impairment, and exercise limitation.

\section{Material and methods}

We selected a study group consisting of blue collar workers with known exposure to asbestos cement dust and symptoms or signs of pulmonary disease. Efforts were made to eliminate confounding factors

Accepted 9 March 1987 by excluding subjects with other occupationalo exposure to noxious inhalants and subjects with sys-⿳亠丷厂巾 temic or pulmonary diseases with no known relation to asbestos exposure but obviously affecting lung function or exercise capacity.

SELECTION OF ST UDY GROUP

In a health survey 758 male former workers at ano asbestos cement factory were screened for pulmonary disease by means of history, physical examination, chest radiography, and spirometry. The medical and 3 . occupational history was obtained both from questionnaires and in an interview. Questions were framed to assess the degree of dyspnoea and the presence of $O$ chronic bronchitis, both according to the criteria adopted by the World Health Organisation. ${ }^{16}$ A detailed smoking history and a history of non pulmonary diseases were also taken. Theô occupational history included the specific tasks the subject had performed during each period of employ 오 ment. Any other occupational exposure to noxious $\omega$ inhalants was noted and subjects with such exposure? were excluded. The first criterion for inclusion into the study group was dyspnoea grade 1 or greatero according to Rose and Blackburn. ${ }^{16}$

The second criterion for inclusion was the finding of persisting crepitations over the lungs at physica䧚 examination. 
Chest radiographs were obtained in the posteroanterior, left lateral, and both oblique projections. Interstitial fibrosis was coded according to the ILO classification $^{17}$ and the third inclusion criterion was code $1 / 0$ or greater.

Spirometry, including $\mathrm{VC}$ and $\mathrm{FEV}_{1}$, was performed with a dry spirometer. The fourth criterion for inclusion was a VC or $\mathrm{FEV}_{1}$ of less than $80 \%$ of the predicted value. ${ }^{18}$

The selection criteria were met by 209 subjects. Twenty two subjects refused further investigation. Severe heart or systemic disease which was judged to be exercise limiting was found in 27 subjects who were excluded from the study group. Eleven had a history of severe obstructive lung disease (bronchial asthma in six cases and chronic bronchitis in five) and were excluded on this account. One subject with asbestosis had been fully investigated at another hospital shortly before the study and was not included. One subject died in the interval between the screening and the physiological study. Ten subjects met one criterion but were clinically judged to be normal and not included in the study group. Most of these had borderline spirometry in combination with low exposure and other likely reasons for the spirometric finding, such as obesity, chest deformity, or poor cooperation. The final study group thus consisted of 137 subjects who were referred for pulmonary function studies at rest and during exercise.

PULMONARY FUNCTION STUDIES AT REST Total lung capacity (TLC), functional residual capacity (FRC), and residual volume (RV) were measured by body plethysmography. ${ }^{19}$ When the subject was breathing against a closed shutter for determination of thoracic gas volume, the breathing frequency was kept below $1 \mathrm{~Hz}$. The validity of using the pressure recorded at the airway opening to estimate intrathoracic pressure variation was ascertained in each case by a comparison with oesophageal pressure, measured with an oesophageal balloon.

Pulmonary resistance $\left(\mathbf{R}_{\mathbf{L}}\right)$ and static elastic recoil pressure $\left(\mathrm{Pel}_{\mathrm{L}}\right)$ were measured with the flow regulator technique described by Jonson. ${ }^{19}$ Lung resistance was recorded over expirations covering most of the vital capacity at a regulated flow of $11 / \mathrm{s}$. $\mathrm{Pel}_{\mathrm{L}}$ was recorded during flow interruptions and $R_{L}$ was measured at a $\mathrm{Pel}_{\mathrm{L}}$ of $7.5 \mathrm{~cm} \mathrm{H}_{2} \mathrm{O}$ specifically to illustrate intrinsic bronchial abnormalities. ${ }^{20}$

The static elastic pressure volume curve was constructed from simultaneous measurements of $\mathrm{Pel}_{\mathbf{L}}$ and thoracic gas volume during an expiration. Static lung compliance $\left(\mathrm{Cst}_{\mathrm{L}}\right)$ was measured over the $\mathrm{Pel}_{\mathrm{L}}$ interval 5 to $15 \mathrm{~cm} \mathrm{H}_{2} \mathrm{O}$. $\mathrm{Pel}_{\mathrm{L}}$ was also measured at maximum inspiration $\left(\mathrm{Pel}_{\mathbf{L}, \mathrm{TLC}}\right)$.
PULMONARY FUNCTION STUDIES

DUR I N G E X E R C ISE

An exercise test was performed with an electrically braked bicycle ergometer. The initial work load was $50 \mathrm{~W}$ with increments of $50 \mathrm{~W}$ every five minutes. Exercise was continued till exhaustion except in a few cases when it was terminated for other reasons. The radial artery was cannulated before the exercise test, arterial blood was sampled at rest and at each work load, and pulmonary mechanics were subsequently studied with a computerised technique. Flow at the airway opening was measured with a Fleisch pneumotachograph and transpulmonary pressure with the oesophageal balloon. Ventilation $\left(V_{E}\right)$ was calculated as

$$
\mathbf{V}_{\mathbf{E}}=\frac{\mathbf{V}}{2 \mathrm{n}}
$$

when $\mathrm{n}$ is the number of readings during a sequence of complete breaths. The factor 2 accounts for the reading during both expiration and inspiration. Tidal volume $\left(V_{T}\right)$ was obtained from $V_{E}$ and breathing frequency $\left(f_{R}\right)$. Dynamic pulmonary compliance $\left(\right.$ Cdyn $\left.n_{L}\right)$ was obtained from

$$
\operatorname{Cdyn}_{L}=V_{T} \times\left(P_{L, E}-P_{L, I}\right)^{-1}
$$

when $P_{L, E}$ and $P_{L, I}$ represent average transpulmonary pressure at the end of expiration and at the end of inspiration.

Work rate against pulmonary resistance (W) was measured. Functional pulmonary resistance $\left(\mathbf{R f}_{\mathbf{L}}\right)$ was calculated according to the principles given by Otis $e t a^{21}$ and applied by Ahlström and Jonson ${ }^{22}$ as

$$
\mathbf{R f}_{\mathbf{L}}=\mathbf{W} \times \mathbf{V}_{\mathbf{E}}^{-2} \times \mathbf{k}
$$

where $\mathbf{k}$ is a constant.

\section{REFER E N CE VAL UES}

$\mathrm{VC}$ and $\mathrm{FEV}_{1}$ were related to the predictions of Berglund $e t$ al. ${ }^{18}$ To obtain reference values for other tests of lung function and for exercise capacity, we studied a group of 49 normal subjects matched to the study group for age and smoking habits. The normal subjects were recruited from among lumberjacks and workers in a slaughter house and a food manufacturing industry and selected on the basis of history and physical examination. Subjects with heart or lung disease, hypertension, diabetes, obesity, dementia, alcoholism, or abnormalities of the locomotor system and those with an occupational history of exposure to noxious inhalants were excluded. A normal routine physical examination was also required. No subject was excluded on the basis of physiological measurements. The reference group was studied according to the same protocol as the study group and the results will be presented in detail elsewhere (Jakobsson $\mathrm{K}$ et al, in preparation). 
D A T A A N L Y I S

In the present paper individual results from subjects in the study group are presented as per cent of the predicted value based on the results from the reference group. Static lung volumes (TLC, FRC, RV), static compliance, and exercise capacity were related to each subject's age and height. $R_{L}, R_{L}, C d y n_{L}$, $\mathrm{PaO}_{2}$, and $\mathrm{PaCO}_{2}$ were expressed as per cent of the mean value found in the reference group. Nonsmokers and smokers were treated separately and exsmokers in the study group (46 subjects) were treated as current smokers.

Student's $t$ test was used for tests of significance between groups. Single or multiple ${ }^{23}$ linear regression analysis was performed by the least squares method. For single regression analysis, the physiological variables were related to predicted values as indicated above, whereas for multiple regression analysis the measured values were used.

ASSESSMENT OF EXPOSURE TO ASBESTOS The asbestos cement industry operated from 1907 to 1977. The asbestos used was almost exclusively chrysotile, which was milled on site before being mixed with cement; wet milling was introduced in 1952. Other systematic efforts to reduce dust concentrations started in the late 1960s. The cement used had a low silica content $(<0 \cdot 1 \%)$.

Dust measurements are available for the period 1956-77 but before 1969 only impinger or gravimetric determinations exist; the membrane filter method was introduced in 1969. Some data from parallel samplings with the different methods are available. The calculated exposure levels are based on the standards used at the time of sampling. The use of present standards for filter preparation and fibre counting would probably result in higher levels of exposure. Before 1969 there is altogether 10 hours of sampling. Extensive sampling was performed after 1975. The average dust exposure for different jobs and periods has bee estimated in fibre $/ \mathrm{ml}(\mathrm{f} / \mathrm{ml})$ from data on dust concen? trations, production, and dust control. ${ }^{24}$ Only mill ers, mixers, and workers performing sawing oper? ations were continually exposed to more than $2 \mathrm{f} / \mathrm{ml}$ Occasional exposure to high dust concentration occurred during unloading of asbestos but it has nof been possible to take this into account. The individua $\$$ time spent performing different tasks has also beetक considered and the individual cumulated exposure expressed as a product of intensity and time in fibre. years per millilitre $(\mathrm{fy} / \mathrm{ml})$.

\section{Results}

Nineteen subjects had a history of breathlessness cor responding to grade 1 or greater according to the WHO criteria. ${ }^{16}$ In 68 subjects crackles were found on auscultation of the lungs and radiological evidence of interstitial fibrosis was present in 13. A VC or $\mathrm{FEV}_{1}$ of less than $80 \%$ of the predicted value was found in 108 subjects. Inclusion in the study grous was based on one criterion in 85 cases (dyspnoea in two cases, crackles in 23 , interstitial fibrosis in one $\stackrel{?}{2}$ and spirometry in 59) and on combinations of criterixo in 52 .

Most subjects in the study group were smokers; 38 had a history of chronic bronchitis ${ }^{25}$ and 15 had history of pleurisy. A history of asthma was present in five subjects, of tuberculosis in two, of pulmonary embolism in one, and of sarcoidosis in one. A history of myocardial infarction was present in eight whereas four had angina pectoris and three showed mild signs of left ventricular failure.

Mean age, height, and weight were similar in the study group and the reference group, and there was no significant difference in smoking history between exposed and non-exposed smokers (table 1)? Exposure to asbestos had a skewed distribution with

Table 1 Characteristics of subjects studied

\begin{tabular}{|c|c|c|c|c|c|c|c|c|}
\hline & & $\begin{array}{l}\text { Age } \\
\text { (years) }\end{array}$ & $\begin{array}{l}\text { Height } \\
(m)\end{array}$ & $\begin{array}{l}\text { Weight } \\
(\mathrm{kg})\end{array}$ & $\begin{array}{l}\text { Smoking } \\
\text { history } \\
\text { (pack years) }\end{array}$ & $\begin{array}{l}\text { Exposure } \\
(f y / m l)\end{array}$ & $\begin{array}{l}V C \\
\text { (\% pred) }\end{array}$ & $\begin{array}{l}F E V_{1} \\
\text { (\% pred) }\end{array}$ \\
\hline \multicolumn{9}{|l|}{ Study group: } \\
\hline $\begin{array}{l}\text { Non-smokers } \\
(n=14)\end{array}$ & $\begin{array}{l}\text { Mean } \\
\text { SD }\end{array}$ & $\begin{array}{l}60 \cdot 9 \\
12 \cdot 7\end{array}$ & $\begin{array}{l}1.71 \\
0.04\end{array}$ & $\begin{array}{l}81 \cdot 5 \\
11 \cdot 0\end{array}$ & 0 & $\begin{array}{l}17 \cdot 6 \\
15 \cdot 4\end{array}$ & $\begin{array}{l}76 \cdot 2 \\
10 \cdot 7\end{array}$ & $\begin{array}{l}85 \cdot 1 \\
12 \cdot 0\end{array}$ \\
\hline $\begin{array}{l}\text { Smokers } \\
(n=123)\end{array}$ & $\begin{array}{l}\text { Mean } \\
\text { SD }\end{array}$ & $\begin{array}{l}59.9 \\
11.6\end{array}$ & $\begin{array}{l}1.73 \\
0.06\end{array}$ & $\begin{array}{l}77 \cdot 5 \\
12 \cdot 1\end{array}$ & $\begin{array}{l}25 \cdot 0 \\
16 \cdot 3\end{array}$ & $\begin{array}{l}20 \cdot 2 \\
27 \cdot 6\end{array}$ & $\begin{array}{l}78 \cdot 6 \\
12 \cdot 3\end{array}$ & $\begin{array}{l}77 \cdot 0 \\
19 \cdot 4\end{array}$ \\
\hline \multicolumn{9}{|l|}{ Reference group: } \\
\hline $\begin{array}{l}\text { Non-smokers } \\
(n=21)\end{array}$ & $\begin{array}{l}\text { Mean } \\
\text { SD }\end{array}$ & $\begin{array}{r}57 \cdot 0 \\
7 \cdot 4\end{array}$ & $\begin{array}{l}1 \cdot 74 \\
0.04\end{array}$ & $\begin{array}{l}77 \cdot 2 \\
10 \cdot 6\end{array}$ & 0 & & $\begin{array}{l}93 \cdot 4 \\
12 \cdot 4\end{array}$ & $\begin{array}{l}97 \cdot 8 \\
11 \cdot 9\end{array}$ \\
\hline $\begin{array}{l}\text { Smokers } \\
(n=28)\end{array}$ & $\begin{array}{l}\text { Mean } \\
\text { SD }\end{array}$ & $\begin{array}{r}55.8 \\
9.6\end{array}$ & $\begin{array}{l}1.73 \\
0.06\end{array}$ & $\begin{array}{r}74 \cdot 7 \\
9 \cdot 5\end{array}$ & $\begin{array}{l}20.9 \\
10.6\end{array}$ & & $\begin{array}{l}89.2 \\
10 \cdot 8\end{array}$ & $\begin{array}{l}90 \cdot 7 \\
12 \cdot 3\end{array}$ \\
\hline
\end{tabular}


Table 2 Lung function measurements at rest. All results are presented as per cent of the value predicted from the reference group

\begin{tabular}{|c|c|c|c|c|c|c|c|}
\hline & & $T L C$ & $F R C$ & $R V$ & Cst $_{L}$ & $R_{L}$ & $P e l_{L, T L C}$ \\
\hline \multicolumn{8}{|l|}{ Study group: } \\
\hline $\begin{array}{l}\text { Non-smokers } \\
(n=14)\end{array}$ & $\begin{array}{l}\text { Mean } \\
\text { SD } \\
\text { p }\end{array}$ & $\begin{array}{l}80 \\
11 \\
<0.001\end{array}$ & $\begin{array}{l}79 \\
14 \\
<0.001\end{array}$ & $\begin{array}{l}83 \\
19 \\
<0.01\end{array}$ & $\begin{array}{l}61 \\
19 \\
<0.001\end{array}$ & $\begin{array}{l}151 \\
63 \\
<0.01\end{array}$ & $\begin{array}{l}126 \\
33 \\
<0.01\end{array}$ \\
\hline $\begin{array}{l}\text { Smokers: } \\
(n=123)\end{array}$ & $\begin{array}{l}\text { Mean } \\
\text { SD } \\
\mathrm{p}\end{array}$ & $\begin{array}{l}89 \\
14 \\
<0.01\end{array}$ & $\begin{array}{l}94 \\
26 \\
\text { NS }\end{array}$ & $\begin{array}{r}102 \\
34 \\
\text { NS }\end{array}$ & $\begin{array}{l}76 \\
21 \\
<0.001\end{array}$ & $\begin{array}{l}165 \\
105 \\
<0.01\end{array}$ & $\begin{array}{r}108 \\
36 \\
\text { NS }\end{array}$ \\
\hline
\end{tabular}

p Values represent comparisons with the reference group (Student's $t$ test).

Table 3 Exercise capacity and lung function measurements at maximum work load. All results are presented as per cent of the value predicted from the reference group

\begin{tabular}{|c|c|c|c|c|c|c|c|c|}
\hline & & $E C$ & $f_{R}$ & $\dot{V}_{E}$ & $C d y n_{L}$ & $R f_{L}$ & $\mathrm{PaO}_{2}$ & $\mathrm{PaCO}_{2}$ \\
\hline \multicolumn{9}{|l|}{ Study group: } \\
\hline $\begin{array}{l}\text { Non-smokers } \\
(\mathrm{n}=11)\end{array}$ & $\begin{array}{l}\text { Mean } \\
\text { SD } \\
\mathrm{p}\end{array}$ & $\begin{array}{l}79 \\
18 \\
<0.001\end{array}$ & $\begin{array}{r}119 \\
35 \\
\text { NS }\end{array}$ & $\begin{array}{l}79 \\
28 \\
\text { NS }\end{array}$ & $\begin{array}{l}64 \\
39 \\
<0.05\end{array}$ & $\begin{array}{l}147 \\
77 \\
<0.05\end{array}$ & $\begin{array}{l}96 \\
14 \\
\text { NS }\end{array}$ & $\begin{array}{r}104 \\
12 \\
\text { NS }\end{array}$ \\
\hline $\begin{array}{l}\text { Smokers } \\
(\mathrm{n}=109)\end{array}$ & $\begin{array}{l}\text { Mean } \\
\text { SD } \\
\text { p }\end{array}$ & $\begin{array}{l}78 \\
21 \\
<0.001\end{array}$ & $\begin{array}{r}99 \\
21 \\
\text { NS }\end{array}$ & $\begin{array}{l}69 \\
17 \\
<0.001\end{array}$ & $\begin{array}{l}74 \\
28 \\
<0.001\end{array}$ & $\begin{array}{l}157 \\
70 \\
<0.001\end{array}$ & $\begin{array}{l}91 \\
12 \\
<0.001\end{array}$ & $\begin{array}{l}106 \\
13 \\
<0.05\end{array}$ \\
\hline
\end{tabular}

p Values represent comparisons with the reference group (Student's $t$ test).

Table 5 Relation between smoking, asbestos exposure, and lung function measured at maximum exercise in the study group. Multiple regression analysis was used and the standardised regression coefficients $(B)$ are presented. This relates the standard deviation unit change in the dependent variable to one standard deviation unit change in the independent variable

\begin{tabular}{|c|c|c|c|c|c|c|c|c|}
\hline & & $E C$ & $f_{R}$ & $\dot{V}_{E}$ & $C d y n_{L}$ & $R f_{L}$ & $\mathrm{PaO}_{2}$ & $\mathrm{PaCO}_{2}$ \\
\hline Smoking & $\begin{array}{l}\text { B } \\
\mathbf{p}\end{array}$ & $\begin{array}{l}-0.176 \\
<0.05\end{array}$ & $\begin{array}{l}0 \cdot 105 \\
\text { NS }\end{array}$ & $\mathrm{NS}^{-0.052}$ & $\mathrm{NS}^{0.031}$ & $\begin{array}{l}0.189 \\
p=0.05\end{array}$ & $\begin{array}{l}-0 \cdot 114 \\
\text { NS }\end{array}$ & $\begin{array}{l}-0.016 \\
\text { NS }\end{array}$ \\
\hline Exposure & $\begin{array}{l}\text { B } \\
\text { p }\end{array}$ & $\begin{array}{l}-0.078 \\
\text { NS }\end{array}$ & $\begin{array}{l}0 \cdot 162 \\
\text { NS }\end{array}$ & $\mathrm{NS}^{0 \cdot 178}$ & $\begin{array}{l}-0.382 \\
<0.001\end{array}$ & $\begin{array}{l}0.066 \\
\text { NS }\end{array}$ & $\begin{array}{l}-0.057 \\
\text { NS }\end{array}$ & $\mathrm{NS}^{0.008}$ \\
\hline
\end{tabular}

a mean in the study group of $19.7 \mathrm{fy} / \mathrm{ml}$. The median exposure was $11.8 \mathrm{fy} / \mathrm{ml}$ and the 10th and 90th percentile $0.9 \mathrm{fy} / \mathrm{ml}$ and $39.5 \mathrm{fy} / \mathrm{ml}$, respectively. The difference in exposure between smokers and nonsmokers was small. The mean duration of exposure was 15.8 years. No subject was occupationally exposed to asbestos at the time of the study. The mean interval between the cessation of exposure and the study was 13.5 years.

Results of the lung function measurements at rest (table 2) showed reduced lung volumes and static lung compliance in the non-smokers exposed to asbestos. Pel $_{\mathrm{L}, \mathrm{TLC}}$ and $\mathrm{R}_{\mathrm{L}}$ were increased. The exposed smokers had significantly reduced TLC and Cst $_{L}$ whereas $R_{L}$ was increased. Lung volumes and Cst $_{L}$ were significantly higher $(\mathrm{p}<0.05)$ in exposed smokers than in exposed non-smokers.

An exercise test to exhaustion could be performed in 120 subjects (table 3 ) in whom exercise was limited by dyspnoea or fatigue. A complete test could not be performed in 17 subjects for various reasons such as development of chest pain or arrythmia. These subjects were omitted from the analysis. Exercise capacity was reduced in non-smokers and in smokers. Maximum heart rate during exercise was $149 \pm 16 \mathrm{~min}^{-1}$ in exposed non-smokers and $140 \pm 22 \mathrm{~min}^{-1}$ in exposed smokers compared with $164 \pm 19 \mathrm{~min}^{-1}$ and $159 \pm 18 \mathrm{~min}^{-1}$ in non-smoking and smoking referents. The difference between exposed subjects and referents is significant both for non-smokers ( $p<0.05$, Student's $t$ test) and smokers $(p<0.001)$. Dynamic compliance was reduced and functional lung resistance was increased both in nonsmokers and in smokers (table 3). Statistically significant abnormalities in gas exchange were observed in the smokers with a small reduction in arterial $\mathrm{PaO}_{2}$ and a small increase in arterial $\mathrm{PaCO}_{2}$. In five subjects $\mathrm{a} \mathrm{OO}_{2}$ below $8 \mathrm{kPa}$ was recorded, the 
Table 5 Relation between smoking, asbestos exposure, and lung function measured at maximum exercise in the study group Multiple regression analysis was used and the standardised regression coefficients $(B)$ are presented. This relates the standard deviation unit change in the dependent variable to one standard deviation unit change in the independent variable

\begin{tabular}{|c|c|c|c|c|c|c|c|c|}
\hline & & $E C$ & $f_{R}$ & $\dot{V}_{E}$ & $C d y n_{L}$ & $R f_{L}$ & $\mathrm{PaO}_{2}$ & $\mathrm{PaCO}_{2}$ \\
\hline Smoking & $\begin{array}{l}\text { B } \\
\text { p }\end{array}$ & $\begin{array}{l}-0.176 \\
<0.05\end{array}$ & $\begin{array}{l}0 \cdot 105 \\
\text { NS }\end{array}$ & $\begin{array}{l}-0.052 \\
\mathrm{NS}\end{array}$ & $\begin{array}{l}0.031 \\
\text { NS }\end{array}$ & $\begin{array}{l}0.189 \\
p=0.05\end{array}$ & $\begin{array}{l}-0 \cdot 114 \\
\text { NS }\end{array}$ & $\begin{array}{l}-0.016 \\
\text { NS }\end{array}$ \\
\hline Exposure & $\begin{array}{l}\text { B } \\
\text { p }\end{array}$ & $\begin{array}{l}-0.078 \\
\text { NS }\end{array}$ & $\begin{array}{l}0 \cdot 162 \\
\text { NS }\end{array}$ & $\mathrm{NS}^{0 \cdot 178}$ & $\begin{array}{l}-0.382 \\
<0.001\end{array}$ & $\begin{array}{l}0.066 \\
\text { NS }\end{array}$ & $\begin{array}{l}-0.057 \\
\text { NS }\end{array}$ & $\mathrm{NS}^{0.008}$ \\
\hline
\end{tabular}

lowest value being $6.5 \mathrm{kPa}$. Two subjects had a $\mathrm{PaCO}_{2}$ above $6 \mathrm{kPa}$ at maximum exercise.

Exposure to asbestos correlated with age by single regression analysis in the study group $(r=0.407$, $\mathrm{p}<0.001$ ) but did not correlate with tobacco consumption in the smokers. The effects of smoking and exposure of asbestos on lung function were examined by multiple regression analysis in the study group. Age, height, and weight were used as background variables. There were positive correlations between smoking and TLC, FRC, and RV and a negative correlation with Pel $_{\mathbf{L}, \mathrm{TLC}}$ (table 4). This is compatible with loss of recoil and a tendency to airway closure and development of emphysema. Smoking was inversely related to exercise capacity and a positive correlation was found between smoking and $\mathbf{R f}_{\mathbf{L}}$ (table 5).

Exposure to asbestos showed negative correlations with TLC, FRC, RV, and $\mathrm{Cst}_{\mathrm{L}}$ and a positive correlation with $\mathrm{Pel}_{\mathrm{L}, \mathrm{TLC}}$ (table 4). These findings are compatible with a fibrogenic effect of asbestos. There was no significant correlation between asbestos cement exposure and exercise capacity, but a significant, negative correlation was found between exposure and $\mathrm{Cdyn}_{\mathrm{L}}$ (table 5). Similar results were obtained when log exposure was used in the regression analysis.

The relation between exercise capacity and lung function variables was investigated with single regression analysis. Several findings indicated a relation between exercise capacity and airflow obstruction. Exercise capacity thus showed negative correlations with FRC, $R V, R_{L}$ and $R_{L}$ (table 6). There was also a significant correlation with $\mathrm{Cst}_{\mathbf{L}}$.
Exercise capacity was not related to blood gases at $\overrightarrow{\vec{\omega}}$ maximum exercise.

\section{Discussion}

Interstitial fibrosis of the lung has been recognised as a consequence of exposure to asbestos since the early part of this century. The condition is generally regarded to be characterised by a history of exposure to asbestos in combination with effort dyspnoea, $\vec{\longrightarrow}$ crepitations, radiographic fibrosis, or impaired lung function.

One consequence of the increasing awareness of the health effects of exposure to asbestos has been that $\vec{\infty}$ large numbers of workers subject to rather low. $v$ exposure in asbestos using industries are being screened for lung function abnormalities and assessed for disability. There is thus a need for information about the physiological effects of low level exposure to asbestos dust, information which cannot be $\mathbb{D}$ obtained from previous studies of workers exposed to asbestos. Disability cannot be estimated reliably from윽 symptoms, radiographic or lung function abnormalities. $^{26}$ An exercise test therefore seems the best way to estimate the functional impairment. For the relation between lung function abnormalities and exercise impairment to be established, a reasonable $\exists$ number of subjects with reduced exercise tolerance has to be studied. In this study we therefore selected workers with symptoms or signs suggestive of lung $\mathrm{O}$ disease. In about $25 \%$ of the subjects who met the inclusion criteria we found diseases that were not pri-으 marily related to the pulmonary effects of asbestosis $>$ but would obviously affect lung function or reduce

Table 6 Relation between exercise capacity and lung function variables in the study group obtained with single regression analyses

\begin{tabular}{|c|c|c|c|c|c|c|c|c|c|c|c|c|}
\hline & & $T L C$ & $F R C$ & $R V$ & $\mathrm{Cst}_{\mathrm{L}}$ & $R_{L}$ & $P e l_{L, T L C}$ & $C d y n_{L}$ & $R f_{L}$ & $\mathrm{PaO}_{2}$ & $\mathrm{PaCO}_{2}$ & ס \\
\hline & & \multicolumn{6}{|c|}{ At rest } & \multicolumn{4}{|c|}{ At maximum exercise } & $\frac{\bar{D}}{D}$ \\
\hline $\begin{array}{l}\text { Exercise } \\
\text { capacity } \\
(\mathrm{n}=120)\end{array}$ & $\begin{array}{l}\mathbf{r} \\
\mathrm{p}\end{array}$ & $\begin{array}{l}-0.08 \\
\mathrm{NS}\end{array}$ & $\begin{array}{l}-0.20 \\
<0.05\end{array}$ & $\begin{array}{l}-0.27 \\
<0.01\end{array}$ & $\begin{array}{l}0.25 \\
<0.01\end{array}$ & $\begin{array}{l}-0.34 \\
<0.001\end{array}$ & $\begin{array}{l}-0.01 \\
\text { NS }\end{array}$ & $\begin{array}{l}0 \cdot 19 \\
\text { NS }\end{array}$ & $\begin{array}{l}-0.48 \\
<0.001\end{array}$ & $\begin{array}{l}-0.06 \\
\text { NS }\end{array}$ & $\begin{array}{l}0 \cdot 10 \\
\text { NS }\end{array}$ & 뭄 \\
\hline
\end{tabular}


exercise capacity. These patients were excluded from the study group. There remains in the study group a proportion of subjects with respiratory or heart disease of milder degree. The subjects with asthma or heart disease are few and in the case of subjects with chronic bronchitis the condition may be related to exposure to dust.

We thought it important to compare the study group with a group of healthy industrial workers, since the exercise capacity in this group is likely to be higher than in the general population. Another reason for this comparison is the evidence for a higher prevalence of airways obstruction ("industrial bronchitis" 27 ) in industrial workers than in the general population.

The selection of the study group and the reference group has some consequences that must be borne in mind when the data are interpreted. It is generally assumed that individual susceptibility to asbestos and to tobacco smoke is highly variable. It must therefore be emphasised that the relation between exposure to asbestos and lung function found in this group of subjects with symptoms and signs of lung disease probably does not apply to the exposed population at large. The group is, however, representative of the subjects who are brought to medical attention either because of symptoms or by signs found in screening procedures. The subjects in the reference group were selected so as not to have a history of chest disease. For smokers, this implies that the group consists of subjects with a low susceptibility to the damaging effects of tobacco smoke. The smokers in the study group, on the other hand, may represent subjects with a high susceptibility to tobacco smoke, and although the tobacco consumption in the two groups does not differ, the physiological effects of smoking may well do.

The accuracy of the asbestos dose estimates is dependent on the occupational history obtained and the dust measurements. The history was compared with the records of the company and with information obtained from a foreman who had been employed for many years. There was, in general, good agreement, suggesting that the duration of exposure was reliably estimated. The information about dust concentrations is limited, especially for the years before 1969. There are also uncertainties associated with the estimation of asbestos fibre exposure from the impinger measurements. In the present study cumulated individual dose showed closer correlation with lung function variables than did individual duration of exposure. A histological study of dead workers from the same plant ${ }^{28}$ showed dose-response relations between the number of ferruginous bodies and cumulated individual exposure as well as the intensity and the duration of exposure. The cumu- lated individual dose showed the closest correlation with ferruginous bodies. These observations indicate that the estimates of the intensity of exposure are acceptable and we believe them to be accurate within a factor of two compared with real values. Exposure levels similar to ours have been presented from another Swedish asbestos cement industry. ${ }^{29}$

As expected, there was a close correlation between age and cumulated exposure in the study group. This should be of little importance since, whenever appropriate, age has been taken into account in the analysis. Tobacco consumption was not related to age or to exposure in the study group, which is important for the differentiation between the pathophysiological effects of smoking and exposure to asbestos.

The findings of reduced lung volumes, increased $\mathrm{Pel}_{\mathbf{L}, \mathrm{TLC}}$, and reduced lung compliance are compatible with a fibrogenic effect of asbestos. The correlations between exposure and physiological variables indicate a causal connection. In most previous studies of the physiological effects of asbestos exposure the cumulated dose has been about one order of magnitude higher than in this study. ${ }^{8-1125}$ Little information is available concerning lower levels of exposure. ${ }^{2930}$ Owing to the selection of the study group, we are not able to estimate the dose related risk of developing interstitial fibrosis in the working population. Our data show, however, that functional abnormalities may be found in susceptible individuals after as little exposure as approximately $20 \mathrm{fy} / \mathrm{ml}$ and they frequently occurred without radiographic signs of interstitial fibrosis. ${ }^{31-33}$ This is in good agreement with the histological study of dead workers from the plant, which also showed interstitial fibrosis after a cumulated exposure of approximately $20 \mathrm{fy} / \mathrm{ml}^{28}$

We found indications of increased airflow obstruction in the study group compared with the reference group (tables 2 and 3 ). This may, as has previously been suggested, be caused by the exposure to asbestos. $^{3-7}$ It may also, however, result from the selection procedure, which favours inclusion of subjects with a high sensitivity to inhaled irritants into the study group and subjects with a low sensitivity into the control group. A multiple regression analysis was performed in the study group to avoid this selection bias (tables 4 and 5). It shows clearly that smoking is related to the presence of obstructive lung disease. Asbestos exposure, on the other hand, is related to lung fibrosis, but there is no correlation with any variable reflecting obstruction. On the basis of this analysis, we conclude that the finding of obstructive lung disease in the study group mainly results from selection bias, and that the fibrogenic effect of asbestos dominates under the conditions studied. This study does not, however, rule out an obstructive effect of low level asbestos exposure, since we did not include 
any technique to study specifically the small airways, which are likely to be first affected.

The abnormalities in gas exchange observed in the study group were of a relatively mild degree. There was a significant reduction in $\mathrm{PO}_{2}$ at maximum work load in the smokers exposed to asbestos (table 3 ) which did not, however, correlate with either the occupational exposure or smoking (tables 4 and 5). Our study thus shows, in agreement with the work of Jodoin et al, ${ }^{3}$ that mechanical abnormalities often precede abnormalities in gas exchange in the development of asbestosis. This sequence of events may be a feature of the preferentially peribronchiolar distribution of fibrosis, ${ }^{34}$ which could reduce lung compliance while leaving the alveolar capillary units less affected.

As expected from the selection procedure, exercise capacity was lower in the study group than in the reference group (table 3 ). In the study group exercise capacity was inversely related to smoking but showed no significant correlation with asbestos exposure (table 5). When exercise capacity was related to measurements of lung function, highly significant, inverse correlations were found with variables reflecting bronchial obstruction $\left(R V, R_{L}\right.$, and $\left.R f_{L}\right)$. There was also a significant correlation between exercise capacity and $\mathrm{Cst}_{\mathbf{L}}$ but neither TLC nor Pel $_{\mathbf{L}, \mathbf{T L C}}$, which correlated with exposure, appeared to be related to exercise capacity. It thus appears that exercise capacity in the study group is related more to airflow obstruction than to interstitial fibrosis. This is in keeping with the results from the multiple regression analysis and indicates that smoking is more important for exercise limitation than asbestos exposure at this level. The results are in good agreement with a previous study of exercise performance in smoking and non-smoking asbestos exposed workers. ${ }^{15}$

This study was supported by grants from the Swedish Work Environment Fund (ASF 79/288), the Swedish Medical Research Council (29X-2872), and the Swedish Association against Heart and Chest Diseases.

\section{References}

1 Parkes WR. Asbestos-related disorders. Br J Dis Chest 1973;67: 261-300.

2 Becklake MR, Fournier-Massey G, Rossiter CE, McDonald JC. Lung function in chrysotile asbestos mine and mill workers of Quebec. Arch Environ Health 1972;24:401-9.

3 Jodoin G, Gibbs GW, Macklem PT, McDonald JC, Becklake MR. Early effects of asbestos exposure on lung function. Am Rev Respir Dis 1971;104:525-35.

4 McDonald JC, Becklake MR, Fournier-Massey G, Rossiter CE. Respiratory symptoms in chrysotile asbestos mine and mill workers of Quebec. Arch Environ Health 1972;24:358-63.

5 Lebowitz MD. Occupational exposures in relation to symptomatology and lung function in a community population. Environ
Res 1977;14:59-67.

6 Harless KW, Watanabe S, Renzetti AD Jr. The acute effects of chrysotile exposure on lung function. Environ Res 1978;16:360-72.

7 Rodriquez-Roisin R, Merchant JEM, Cochrane GM, Hickey BPH, Turner-Warwick M, Clark TJH. Maximal expiratory flow volume curves in workers exposed to asbestos. Respiration 1980;39:158-65.

8 Weill H, Waggenspack C, Bailey W, Ziskind M, Rossiter C. Radiographic and physiologic patterns among workers $₫$ engaged in manufacture of asbestos cement products. $J$ Occup Med 1973;15:248-52.

9 McDonald JC, Becklake MR, Gibbs GW, McDonald AD, $\vec{\circ}$ Rossiter CE. The health of chrysotile asbestos mine and mill workers of Quebec. Arch Environ Health 1974;28:61-8.

10 Weill H, Ziskind MM, Waggenspack C, Rossiter CE. Lung function consequences of dust exposure in asbestos cement manufacturing plants. Arch Environ Health 1975;30:88-97.

11 Berry G, Gilson JC, Holmes S, Lewinsohn HC, Roach SA. Asbestosis: a study of dose-response relationships in an asbestos textile factory. Br J Ind Med 1979;36:98-112.

12 Epler GR, Saber FA, Gaensler EA. Determination of severe ir impairment (disability) in interstitial lung disease. Am Rev $\stackrel{+}{\mathrm{N}}$ Respir Dis 1980;121:647-59.

13 Pearle J. Exercise performance and functional impairment in $\mathrm{O}$ asbestos-exposed workers. Chest 1981;80:701-5.

14 Howard J, Mohsenifar Z, Brown HV, Koerner SK. Role of exercise testing in assessing functional respiratory impairment due to asbestos exposure. J Occup Med 1982;24:685-9.

15 Sue DY, Oren A, Hansen JE, Wasserman K. Lung function and exercise performance in smoking and nonsmoking asbestosexposed workers. Am Rev Respir Dis 1985;132:612-8.

16 Rose GA, Blackburn H. Cardiovascular survey methods. Geneva: World Health Organisation, 1968.

17 International Labour Office. ILO U/C classification of radiographs of the pneumoconioses 1971. Geneva: International Labour Office, 1972. (Occupational Health and Safety Series No 22.)

18 Berglund E, Birath G, Bjure J, et al. Spirometric studies in normal subjects. I. Forced expirograms in subjects between 7 and 70 years of age. Acta Med Scand 1963;173:185-92.

19 Jonson B. A method for determination of pulmonary elastic recoil and resistance at a regulated flow rate. Scand J Clin Lab Invest 1969;24:115-25.

20 Jonson B. Pulmonary mechanics in patients with pulmonary disease studied with the flow regulator method. Scand J Clin Lab Invest 1970;25:374-90.

21 Otis AB, McKerrow CB, Bartlett RA, et al. Mechanical factors in distribution of pulmonary ventilation. $J$ Appl Physiol 1956;8:427-43.

22 Ahlström H, Jonson B. Pulmonary mechanics in infants. Meth- $\delta$ odological aspects. Scand J Respir Dis 1974;55:129-40.

23 Nie N, Hull CH, Jenkisn JG, Steinbrenner K, Bent DH. Statistical package for social sciences. 2nd ed. New York: McGraw

Hill, 1975.
24 Welinder H. Asbestexponering $i$ en asbestcementindustri. Lund, $\frac{D}{\text { O }}$ Sweden: University Hospital, 1983. (Report No 831027 from
Department of Occupational Medicine.)

25 Committee on the aetiology of chronic bronchitis of the Medical Research Council. Definition and classification of chronic $\mathbb{S}$ bronchitis. Lancet 1965; i:775-9.

26 Becklake MR. Asbestos-related diseases of the lung and other organs: their epidemiology and implications for clinical practice. Am Rev Respir Dis 1976;114:187-227.

27 Morgan WKC. Industrial bronchitis. Br J Ind Med 1978;35:285-91.

28 Johansson L, Albin M, Jakobsson K, Welinder H, Ranstam J." Histological examination of ferruginous bodies and pulmonary fibrosis in dead low exposed asbestos cement workers. $\mathrm{Br}$ J Ind Med 1987;44:550-8. 
29 Ohlsson CG, Rydman T, Sundell L, Bodin L, Hogstedt C. Decreased lung function in long-term asbestos cement workers: a cross-sectional study. Am J Ind Med 1984;5:359-66.

30 Murphy RLH Jr, Gaensler EA, Redding RA, et al. Low exposure to asbestos. Arch Environ Health 1972;25:253-64.

31 Williams R, Hugh-Jones P. The significance of lung function changes in asbestosis. Thorax 1960;15:109-19.

32 Leathart GL. Pulmonary function tests in asbestos workers.
Transactions of the Society of Occupational Medicine 1968;18:49-55.

33 Bader ME, Bader RA, Teirstein AS, Miller A, Selikoff IJ. Pulmonary function and radiographic changes in 598 workers with varying duration of exposure to asbestos. Journal of Mount Sinai Hospital 1970;37:492-500.

34 Hourihane DO'B, McCaughey WTE. Pathological aspects of asbestosis. Postgrad Med J 1966;42:613-21.

\section{Correspondence and editorials}

The British Journal of Industrial Medicine welcomes correspondence relating to any of the material appearing in the journal. Results from preliminary or small scale studies may also be published in the correspondence column if this seems appropriate. Letters should be not more than 500 words in length and contain a minimum of references. Tables and figures should be kept to an absolute minimum. Letters are accepted on the understanding that they may be subject to editorial revision and shortening.

The journal now also publishes editorials which are normally specially commissioned. The Editor welcomes suggestions regarding suitable topics; those wishing to submit an editorial, however, should do so only after discussion with the Editor. 